\title{
Influence of energy and nitrogen contents of enteral diets on nitrogen balance: a double blind prospective controlled clinical trial
}

\author{
R G P REES, T M COOPER, R BEETHAM, P G FROST, AND D B A SILK \\ From the Department of Gastroenterology and Nutrition, Central Middlesex Hospital and Department of \\ Clinical Pathology, St Bartholomew's Hospital, London
}

SUMmARY Results of recent controlled studies show that because of difficulties in administering adequate quantities of enteral diet, positive nitrogen balance is not consistently achieved during enteral feeding. In order to determine whether nitrogen balance can be improved in routine clinical practice by prescribing enteral diets containing higher concentrations of nutrients, 118 patients with normal gastrointestinal function needing enteral nutrition were randomised to receive daily 21 of one of three polymeric diets: Standard diet (1.0 kcal/ml; 6.3 gN/l), Energy Dense diet (1.5 kcal/ml; 7.8 gN/l), and Energy-Nitrogen Dense diet $(1.5 \mathrm{kcal} / \mathrm{ml} ; 9.4 \mathrm{gN} /$. The three diets, administered by continuous nasogastric infusion, were equally well tolerated. Results were analysed only for patients fed five or more days and who received at least $60 \%$ of prescribed enteral diet $(n=42)$. Positive nitrogen balance was achieved only in the patients receiving the Energy-Nitrogen Dense diet $(n=16$; +1.6 (SE) 0.6 gN/d, compared with the Standard diet $(\mathrm{n}=12 ;-3.8(1.1) \mathrm{gN} / \mathrm{d} ; \mathrm{p}<0.001)$, and the Energy Dense diet $(m=14 ;-1.9(0.8) \mathrm{gN} / \mathrm{d} ; \mathrm{p}<0.005)$. As the findings of this prospective controlled trial show that positive nitrogen balance was not consistently achieved by administering $2 \mathrm{I}$ enteral diet containing up to $15.6 \mathrm{gN}$, consideration could, therefore, be given to routinely using enteral diets containing up to $9 \cdot 4 \mathrm{gN} /$.

Enteral nutrition is now an accepted method of providing nutritional support to patients with normal or near normal gastrointestinal function. The most widely used administration technique usually comprises 24 hour infusion of a formulated enteral diet, with or without the use of a peristaltic pump, through nasal fine bore feeding tubes positioned in the stomach or small intestine. ${ }^{2}$

Results of recent controlled studies show that positive nitrogen balance is often difficult to achieve consistently over a 10 to 20 day period of enteral nutrition. $^{3-6}$ In traumatised or septic patients, particularly those with head injuries, ${ }^{3}$ even an

Address for correspondence: Dr D B A Silk, Department of Gastroenterology and Nutrition, Central Middlesex Hospital, Acton Lane, London NW10 7NS.

Received for publication 29 June 1988. adequate intake of nitrogen and calories may not overcome the primary neuroendocrinological responses and patients will remain in overall negative nitrogen balance. In other patients, negative nitrogen balance is more likely to remain on account of inadequate nutritional intake. Reasons for this have been shown to be related to the use of small containers, ${ }^{5}$ the use of 'starter' regimes, ${ }^{6}$ and the poor performance of fine bore feeding tubes. ${ }^{7}$ On account of these limitations, we have observed that in practice it is often difficult to administer more than $2-2.51$ of enteral diet per day.

Most patients currently requiring enteral nutrition are prescribed a diet containing $1 \mathrm{kcal} / \mathrm{ml}$ and 5 to $6 \mathrm{gN} / 1 .^{8}$ In the light of the technical difficulties that lead to restrictions in the volumes of diet actually administered to patients, ${ }^{56}$ it seemed to us that an 
alternative method of increasing nutritional intake would be to prescribe enteral diets containing higher concentrations of nutrients. We here present the results of a double blind, prospective, controlled clinical trial, designed to test the hypothesis that nitrogen balance in routinely ward fed patients with clinically normal gastrointestinal function can be improved by administering polymeric diets of increased energy and nitrogen density.

\section{Methods}

PATIENTS, MATERIALS, AND DIETARY REGIMES All adult patients who in the opinion of the nutritional support team required enteral nutrition as the sole means of nutritional intake and in whom there was no clinical evidence of impaired luminal nutrient digestion or absorptive capacity were considered for entry into the study. Patients were referred from all specialties throughout the hospital and included hypercatabolic patients known to have urinary nitrogen losses in excess of $15 \mathrm{~g}$ daily. Patients in whom fluid restriction was indicated - for example, those with cardiac, respiratory, hepatic, or renal failure, or inappropriate secretion of antidiuretic hormone $(\mathrm{ADH})$, diabetics, and those with recent diarrhoea, vomiting or regurgitation of gastric contents were all excluded from the study. The study included 118 patients over a 18 month period (November 1984 to April 1986) who constituted $43.5 \%$ of 271 patients receiving nutritional support during the same period. Fifty nine $(21 \cdot 8 \%)$ received total parenteral nutrition. The remaining $94(34 \cdot 7 \%)$ were treated with various enteral regimes outside the trial.

Having satisfied inclusion criteria, 118 patients were randomised, by the drawing of numbered envelopes containing cards allocated by random numbers, to receive 21 daily of one of three

Table 1 Composition of prescribed enteral diet ( $2 l)$

\begin{tabular}{lccc}
\hline & & $\begin{array}{c}\text { Energy } \\
\text { Dense }\end{array}$ & $\begin{array}{l}\text { Energy- } \\
\text { Nitrogen Dense }\end{array}$ \\
\hline Patients (n) & 41 & 38 & 39 \\
Total energy* (kcal) & 2000 & 3000 & 3000 \\
Nitrogen (g) & $12 \cdot 6$ & $15 \cdot 6$ & $18 \cdot 8$ \\
Carbohydrate (g) & 240 & 358 & 360 \\
Fat (g) & 80 & 130 & 120 \\
Sodium (mmol) & 70 & 70 & 70 \\
Potassium (mmol) & 77 & 77 & 77 \\
Phosphorus (mmol) & 32 & 32 & 37 \\
Zinc (mmol) & $0 \cdot 2$ & $0 \cdot 2$ & $0 \cdot 2$ \\
Non-protein energy: N (kcal/g) & $134: 1$ & $167: 1$ & $134: 1$ \\
Osmolality (mmol/kg) & 300 & 410 & 550 \\
& & & \\
\hline
\end{tabular}

$* 100 \mathrm{kcal}=4 \cdot 18 \mathrm{MJ}$. proprietary polymeric diets: (i) Fortison Standard, $1.0 \mathrm{kcal} / \mathrm{ml}, 6.3 \mathrm{gN} / \mathrm{l}$ (Cow and Gate Ltd, Trowbridge, Wilts). Standard diet, $n=41$; (ii) Fortison Plus, $1.5 \mathrm{kcal} / \mathrm{ml}, 7.8 \mathrm{gN} / \mathrm{l}$ (Cow and Gate Ltd). Energy Dense diet, $n=38$; (iii) Nutrison, $1.5 \mathrm{kcal} / \mathrm{ml}$, $9.4 \mathrm{gN} / \mathrm{l}$ (Nutricia, Zoetermeer, Holland). EnergyNitrogen Dense diet, $\mathrm{n}=39$.

The composition of the three diets is summarised in Table 1. All were manufactured at the same location using cows' milk casein, prepared from the same milk supply, as the nitrogen source. The protein content of the three diets would, therefore, have been of near identical amino acid pattern. Glucose polymers and long chain triglycerides constituted the carbohydrate and lipid components respectively of the non-protein energy source. Compared with the Standard diet, the Energy Dense and EnergyNitrogen Dense diets contained $50 \%$ more energy, and $24 \%$ and $50 \%$ more nitrogen respectively; and as a consequence they were both hypertonic compared with plasma.

Nutritional support through the enteral route was continued until no longer clinically indicated or until the patient was ready to start oral feeding.

\section{TECHNIQUE OF ADMINISTRATION}

Patients were intubated with a fine bore $(2.10 \mathrm{~mm}$ od, $1.37 \mathrm{~mm}$ id) nasogastric feeding tube (Corpak Co, Wheeling, Il, USA). ${ }^{9}$ Two litres of full strength diet were prescribed from the outset of day 1 . Starter regimes $^{6}$ were not used in any of the patients and enteral diets were infused continuously over 24 hours from 11 plastic containers. Enteral feeding pumps were not used routinely during the study.

NUTRITIONAL STATUS

Nutritional status of the patients was assessed before randomisation and at weekly intervals thereafter. Anthropometric assessment included measurement of triceps skinfold thickness and midarm circumference. ${ }^{10}$ Biochemical measurements included measurement of plasma albumin," transferrin," thyroxine binding pre-albumin (TBPA), " and retinol binding protein (RBP). ${ }^{12}$ Haematological assessment for total lymphocyte count was also made.

\section{INTAKE OF ENTERAL DIET AND NITROGEN}

BA L A NCE

The quantities of each of the three diets actually infused were recorded for individual patients on a daily basis. The aim throughout was to make continuous 24 hour urine collections for each patient. Total urinary nitrogen was determined on aliquots of urine using a chemiluminescence technique. ${ }^{13}$ Daily nitrogen balances were then calculated from documented dietary intakes and measured urinary losses. 
Table 2 Comparability of patients fed five or more days and who received $60 \%$ or more of prescribed enteral diet

\begin{tabular}{|c|c|c|c|}
\hline Diet & Standard & $\begin{array}{l}\text { Energy } \\
\text { Dense }\end{array}$ & $\begin{array}{l}\text { Energy- } \\
\text { Nitrogen } \\
\text { Dense }\end{array}$ \\
\hline Patients (n) & 12 & 14 & 16 \\
\hline $\begin{array}{l}\text { Age (median) (yr) } \\
\text { (range) }\end{array}$ & $\begin{array}{l}69 \\
(17-77)\end{array}$ & $\begin{array}{l}44 \\
(19-72)\end{array}$ & $\begin{array}{l}55 \\
(17-85)\end{array}$ \\
\hline \multicolumn{4}{|l|}{ Sex } \\
\hline Men & 6 & 12 & 9 \\
\hline Women & 6 & 2 & 7 \\
\hline $\begin{array}{l}\text { Urinary creatinine } \\
\text { (median) }(\mathrm{g} / \mathrm{d}) \\
\text { (range) }\end{array}$ & $\begin{array}{c}0.61 \\
(0.47-1.09)\end{array}$ & $\begin{array}{c}0 \cdot 60 \\
(0 \cdot 47-1 \cdot 14)\end{array}$ & $\begin{array}{c}0 \cdot 65 \\
(0 \cdot 5-1 \cdot 37)\end{array}$ \\
\hline Diagnostic category & & & \\
\hline Neurological & 1 & 4 & 3 \\
\hline Neurosurgical & 2 & 3 & 1 \\
\hline Peri-operative & 3 & 2 & 4 \\
\hline Multiple trauma & 2 & 2 & 3 \\
\hline Medical & 4 & 3 & 5 \\
\hline $\begin{array}{l}\text { Duration of feeding } \\
\text { (median) } \\
\text { (range) }\end{array}$ & $\begin{array}{l}9 \\
(5-38)\end{array}$ & $\begin{array}{l}10 \\
(7-28)\end{array}$ & $\begin{array}{l}13 \\
(5-29)\end{array}$ \\
\hline $\begin{array}{l}\text { \% Prescribed diet administered } \\
\text { (median) } \\
\text { (range) }\end{array}$ & $\begin{array}{l}\text { d } 90 \cdot 1 \\
(82 \cdot 9-99 \cdot 5)\end{array}$ & $\begin{array}{l}85 \cdot 6 \\
(73 \cdot 9-99 \cdot 3\end{array}$ & $\begin{array}{l}89 \cdot 1 \\
(81 \cdot 8-99 \cdot 8)\end{array}$ \\
\hline
\end{tabular}

\section{GASTROINTESTINAL SYMPTOMS}

Each patient was assessed daily by a member of the Nutrition Team and, whenever possible, the presence or absence of feeding related symptoms (nausea, cramps, colic, and diarrhoea) were recorded from direct questioning using a standard questionnaire. ${ }^{14}$

\section{STATISTIC ANALYSIS}

Data concerning nutritional status and metabolic parameters were assessed for statistical significance using Wilcoxon's rank-sum test for paired data. Statistical significance of differences in nitrogen balance were determined using the Mann Whitney U test.

\section{Results}

PATIENT COMPARABILITY (Table 2)

In order to enable the best comparison of the nutritional efficacy of the three diets, data were analysed only for those patients who had completed five or more days of enteral nutrition and received $60 \%$ or more of prescribed enteral diet during the course of enteral feeding. Patients receiving the Standard diet tended to be older, although there was no significant difference in age between the three groups. There were far fewer women in the Energy Dense diet group, but this should not have influenced the results. Daily urinary creatinine excretions, calculated from collections made during the first three days of enteral nutrition as an index of muscle mass ${ }^{15}$ were comparable. The ranges of creatinine excretion reflected the varying muscle mass of patients consequent to wasting and sex differences.

The three groups were also comparable with respect to underlying clinical diagnosis, with similar numbers of each category within each diet group. Neurosurgical patients included those with head injuries and intracranial haemorrhage. Neurological patients were predominantly those with cerebrovascular disease who had swallowing disorders. Importantly, the three groups contained multiple trauma patients who were hypercatabolic when nutritional support was instituted and in whom one might have expected difficulties to occur in achieving overall positive nitrogen balance. ${ }^{16}$

Medical categories included patients with respiratory disease and heart failure and those with anorexia after acute pancreatitis and treatment for tuberculosis. Sepsis, defined as infection giving rise to fever, tachycardia and leukocytosis on more than one day, either as the primary or secondary diagnosis, was distributed evenly between the three groups.

The exclusion of patients fed for less than five days or who, for unexplained reasons, received less than $60 \%$ of prescribed enteral diet allowed for well matched groups, with respect to duration of feeding and proportion of prescribed diet administered, of those patients finally analysed. Of the 118 patients who entered the study, $42(35 \cdot 6 \%)$ were included in the final analysis, $46(39.0 \%)$ were fed for less than five days, and $30(25.4 \%)$ received less than $60 \%$ prescribed enteral diet.

\section{COMPLETION OF FEEDING}

The reasons for termination of enteral nutrition, according to final analysis, for all patients entered into the study are shown in Table 3 . A total of $54 \%$ patients either returned to oral feeding or proceeded to elective surgery. There was no significant differences between any of the treatment groups with respect to any of the end points of the trial. In particular, enteral nutrition was stopped on account of gastrointestinal side effects, including diarrhoea and gastric regurgitation, in almost equally small numbers in each group.

EFFECT OF NUTRITIONAL SUPPORT ON NUTRITIONAL STATUS (Table 4)

The effect of enteral nutrition on nutritional status for each of the three diets was compared by taking the initial and final nutritional parameters recorded for each patient completely studied. There were no significant changes in anthropometric parameters within any treatment group. With regard to plasma protein concentrations, no significant changes for any 
Table 3 End points of trial and patient analysis

\begin{tabular}{|c|c|c|c|c|c|c|c|c|c|}
\hline \multirow{2}{*}{$\begin{array}{l}\text { Diet } \\
\text { Total patients }(n) \\
\text { Administration of enteral diet }\end{array}$} & \multicolumn{3}{|c|}{$\begin{array}{l}\text { Standard } \\
n=41\end{array}$} & \multicolumn{3}{|c|}{$\begin{array}{l}\text { Energy Dense } \\
n=38\end{array}$} & \multicolumn{3}{|c|}{$\begin{array}{l}\text { Energy-Nitrogen Dense } \\
n=39\end{array}$} \\
\hline & $<5 d^{*}$ & $<60 \%+$ & $\begin{array}{l}\text { Data } \\
\text { analysed }\end{array}$ & $<5 d$ & $<60 \%$ & $\begin{array}{l}\text { Data } \\
\text { analysed }\end{array}$ & $<5 d$ & $<60 \%$ & $\begin{array}{l}\text { Data } \\
\text { analysed }\end{array}$ \\
\hline \multicolumn{10}{|l|}{ Patients (n) } \\
\hline 1 Returned to oral feeding & 7 & 6 & 6 & 5 & 8 & 8 & 3 & 3 & 10 \\
\hline $\begin{array}{l}2 \text { Elective preoperative feeding } \\
\text { terminated by surgery }\end{array}$ & - & 1 & 1 & 1 & - & 1 & 2 & 2 & 0 \\
\hline 3 Transferred to other hospitals & 3 & - & 2 & 4 & - & 1 & 4 & - & 1 \\
\hline $\begin{array}{l}4 \text { Gastrointestinal side effects } \\
\text { necessitating cessation of } \\
\text { feeding }\end{array}$ & 2 & - & 1 & 3 & - & - & 3 & - & 1 \\
\hline $\begin{array}{l}5 \text { Deterioration in clinical } \\
\text { condition }\end{array}$ & 1 & 2 & 1 & - & - & 2 & - & 1 & 2 \\
\hline 6 Death & 4 & 3 & 1 & 2 & 1 & 2 & 2 & 3 & 2 \\
\hline
\end{tabular}

*Received less than 5 days of enteral nutrition; †Received less than $60 \%$ of prescribed enteral diet during the course of enteral feeding.

of the proteins studied were seen in patients receiving the Standard diet and no significant changes were recorded for either albumin or TBPA within any patient group. Patients receiving the Energy Dense diet showed a highly significant increase in the level of RBP $(p<0.005)$. The level of this plasma transport protein again increased to the same level of significance in those patients who received the EnergyNitrogen Dense diet, plus a significant increase in the level of transferrin $(p<0.05)$. The total lymphocyte count also showed a significant increase $(p<0.05)$ within patients receiving either of the nutrient dense diets, but not within those receiving the Standard diet.

\section{NITROGEN BALANCE}

In comparing the nitrogen balance data for the three diets, the first five to seven daily nitrogen balances were taken for each patient and the data pooled. This was done with the aim of obtaining representative data of equal weighting for all patients. It can be seen in Table 5 that for the three diets the mean daily output of nitrogen remained remarkably constant, irrespective of changes in energy and protein intake. Hence, mean daily nitrogen balance (Figure) was directly related to nitrogen intake alone, and was positive only in patients who received the EnergyNitrogen Dense diet (+1.6 (SE) $0.6 \mathrm{gN} / \mathrm{d})$. It was then considerably higher than in patients who received either the Standard diet $(-3.8(1 \cdot 1) \mathrm{gN} / \mathrm{d}$; $\mathrm{p}<0.001)$ or the Energy Dense diet $(-1.9(0.8) \mathrm{gN} / \mathrm{d}$; $\mathrm{p}<0 \cdot 005)$.

\section{GASTROINTESTINAL SIDE EFFECTS}

All three enteral diets were equally well tolerated at full strength from the onset of enteral feeding.

Table 4 Nutritional status of patients fed five or more days and who received $60 \%$ or more of prescribed enteral diet

\begin{tabular}{|c|c|c|c|c|c|c|}
\hline \multirow[t]{2}{*}{$\begin{array}{l}\text { Diet } \\
\text { Patients (n) }\end{array}$} & \multicolumn{2}{|l|}{$\begin{array}{l}\text { Standard } \\
12\end{array}$} & \multicolumn{2}{|l|}{$\begin{array}{l}\text { Energy Dense } \\
14\end{array}$} & \multicolumn{2}{|c|}{$\begin{array}{l}\text { Energy-Nitrogen Dense } \\
16\end{array}$} \\
\hline & Before & After & Before & After & Before & After \\
\hline \multicolumn{7}{|l|}{ Triceps skin fold } \\
\hline $\operatorname{Men}(7 \cdot 5-11.3 \mathrm{~mm})^{*}$ & $7 \cdot 8(2 \cdot 1)$ & $7 \cdot 2(1 \cdot 4)$ & $7 \cdot 0(0 \cdot 8)$ & $7 \cdot 1(0 \cdot 7)$ & $6 \cdot 8(0 \cdot 4)$ & $7 \cdot 1(0 \cdot 5)$ \\
\hline Women $(9.9-14.9 \mathrm{~mm})^{*}$ & $13 \cdot 0(2 \cdot 5)$ & $14 \cdot 0(2 \cdot 7)$ & $19 \cdot 3(n=2)$ & $20 \cdot 1(n=2)$ & $14 \cdot 9(2 \cdot 9)$ & $15 \cdot 0(2 \cdot 6)$ \\
\hline \multicolumn{7}{|l|}{ Midarm circumference } \\
\hline $\operatorname{Men}(17 \cdot 6-26 \cdot \dot{3} \mathrm{~cm})^{*}$ & $23 \cdot 6(1 \cdot 9)$ & $22 \cdot 9(1 \cdot 4)$ & $23 \cdot 9(0 \cdot 6)$ & $23 \cdot 9(0 \cdot 7)$ & $24 \cdot 2(0 \cdot 9)$ & $24 \cdot 0(0 \cdot 8)$ \\
\hline Women $(17 \cdot 1-25 \cdot 7 \mathrm{~cm})^{*}$ & $26 \cdot 5(2 \cdot 0)$ & $25 \cdot 6(1 \cdot 9)$ & $26 \cdot 8(n=2)$ & $27 \cdot 1(n=2)$ & $23 \cdot 1(1 \cdot 8)$ & $23 \cdot 0(1 \cdot 5)$ \\
\hline Albumin $\mathrm{g} / \mathrm{l}(35 \cdot 0) \dagger$ & $27 \cdot 2(2 \cdot 6)$ & $27 \cdot 5(2 \cdot 5)$ & $29.5(1.4)$ & $29 \cdot 3(1 \cdot 7)$ & $27 \cdot 7(1 \cdot 8)$ & $29 \cdot 2(1 \cdot 6)$ \\
\hline Transferrin $\mathrm{g} / \mathrm{l}(2 \cdot 0) \dagger$ & $2 \cdot 11(0 \cdot 23)$ & $2 \cdot 21(0 \cdot 20)$ & $1 \cdot 83(0 \cdot 15)$ & $1.92(0 \cdot 18)$ & $1 \cdot 73(0 \cdot 18) \ddagger$ & $2 \cdot 24(0 \cdot 15) \ddagger$ \\
\hline TBPA mg/l $(290) \dagger$ & $250(44)$ & $280(33)$ & $230(30)$ & $250(30)$ & $200(20)$ & $270(24)$ \\
\hline $\mathrm{RBP} \mathrm{mg} / \mathrm{l}(29) \dagger$ & $34 \cdot 8(6 \cdot 3)$ & $42 \cdot 8(4 \cdot 7)$ & $29 \cdot 3(3 \cdot 5)^{* *}$ & $42 \cdot 3(3 \cdot 5)^{* *}$ & $33 \cdot 6(4 \cdot 7) \|$ & $52 \cdot 0(4 \cdot 1) \|$ \\
\hline Lymphocyte count $\times 10^{9} / 1(1 \cdot 5) \dagger$ & $2 \cdot 06(0 \cdot 28)$ & $1 \cdot 89(0 \cdot 16)$ & $1 \cdot 32(0 \cdot 14) \Upsilon$ & $1.83(0 \cdot 20) \rrbracket$ & $1 \cdot 14(0 \cdot 18) \S$ & $2 \cdot 55(0 \cdot 80) \S$ \\
\hline
\end{tabular}

*Values in parentheses represent $60-90 \%$ of adult reference standard values; †Lower limit of normal: $\ddagger p<0.05 ; \$ p<0 \cdot 05 ; \| p<0 \cdot 005$; १ी $<<0 \cdot 05 ; \S \mathrm{p}<0 \cdot 05 ;{ }^{* *} \mathrm{p}<0.005$.

(All values are means (SE)). 
Table 5 Nitrogen intake and output data of patients fed five or more days and who received $60 \%$ or more of prescribed enteral diet

\begin{tabular}{llll}
\hline & Standard & $\begin{array}{l}\text { Energy } \\
\text { Dense }\end{array}$ & $\begin{array}{l}\text { Energy- } \\
\text { Nitrogen Dense }\end{array}$ \\
\hline Patient feeding days (n) & 77 & 74 & 84 \\
Intake of nitrogen (g/d) & $11 \cdot 4(0 \cdot 2)$ & $13 \cdot 2(0 \cdot 3)$ & $16 \cdot 9(0 \cdot 2)$ \\
Output of nitrogen (g/d) & $15 \cdot 0(1 \cdot 1)$ & $14 \cdot 9(0 \cdot 7)$ & $15 \cdot 3(0 \cdot 5)$ \\
\hline
\end{tabular}

(All values are means $(\mathrm{SE})$ ).

Gastrointestinal side effects were recorded in a total of only 13 patients $(11 \%)$ and in only 10 patients $(8.5 \%)$ were they sufficiently serious to preclude further enteral feeding. Diarrhoea, defined as the increased passage of watery stools, noted either by the patient or nursing staff, occurred in a total of only five patients. These were accounted for by one patient in the Energy-Nitrogen Dense treatment group and two each in the Standard and Energy Dense groups. In only two patients did uncontrollable diarrhoea necessitate the cessation of enteral nutrition, and in both instances this was after five days of feeding. This occurred in one stroke patient receiving the Standard diet and in one postoperative gastroenterostomy patient allocated the EnergyNitrogen Dense diet. Neither patient was receiving antibiotics. Abdominal bloating with discomfort was a cause of patient withdrawal on three occasions, one for each of the treatment groups. In all instances the complication appeared to be a consequence of inadvertent rapid infusion of enteral diet. Regurgita-

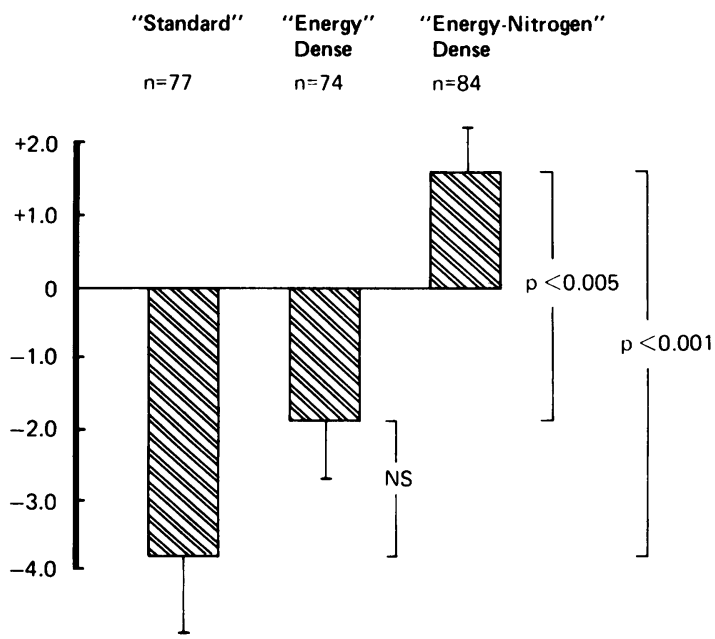

Figure Mean daily nitrogen balance for the three treatment groups ( $g N / d(S E))$ ( $n=$ patient days). tion of gastric contents occurred in a total of five patients and their enteral nutrition was stopped. All were neurological patients with a depressed level of consciousness. One patient was from the Standard diet group and two from each from the Energy Dense and Energy-Nitrogen Dense groups. In none was there clinical or radiological evidence of pulmonary aspiration.

\section{METABOLIC SIDE EFFECTS}

No patient was withdrawn from the study because of metabolic complications. Screening of blood urea, electrolytes and glucose, together with liver function tests were carried out regularly in all patients throughout the study. There was no statistically significant difference in any biochemical parameter within any treatment group, except for plasma sodium concentration in the Energy-Nitrogen Dense treatment group. This then increased from 136 (SE) 1.2 to $139(1.0) \mathrm{mmol} / \mathrm{l}(\mathrm{p}<0.05)$ and no patient became hypernatraemic.

\section{Discussion}

The results of this prospective double blind trial clearly show that as far as nitrogen retention is concerned the best results were obtained in the group of patients receiving the nitrogen and energy dense polymeric diet containing $9.4 \mathrm{gN} / 1$ and $1.5 \mathrm{kcal} / \mathrm{ml}$. Moreover, the group of patients receiving this diet was the only one to achieve overall positive nitrogen balance during the first five to seven days of enteral feeding, as well as the only one in which a significant increase in plasma transferrin occurred. Even if stool nitrogen losses of $1 \mathrm{~g} / \mathrm{d},{ }^{17}$ with skin and miscellaneous losses of up to $8 \mathrm{mg} / \mathrm{kg} / \mathrm{d}^{18}$ were allowed for, patients fed the nitrogen and energy dense diet would be expected to still show a positive nitrogen balance. The clinical significance of these results has to be interpreted, however, in the light of the experimental design.

The primary aim of our clinical research programme in the area of enteral nutrition has been to simplify and improve the techniques of administration of enteral diets and to optimise nutrient assimilation, all in the average ward setting so that the principles gained can be easily applied in the nonspecialist setting. ${ }^{19}$ It has been our experience that in the average ward setting it is difficult to constantly administer more than 2.0 to 2.51 polymeric diet/ $24 \mathrm{~h} .{ }^{56}$ Consequently experimental design was based on a fixed intake of $21 \mathrm{diet} / 24 \mathrm{~h}$. It has often been suggested that the energy and nitrogen requirements of patients requiring enteral nutrition should be routinely assessed prospectively on an individual basis, and then according to this calculated require- 
ment the most appropriately formulated diet prescribed. Although a number of techniques for assessing energy requirements have been described, ${ }^{20}$ the most reliable in our experience is indirect calorimetry, ${ }^{21}$ this in turn having a significant cost implication and a requirement for specific expertise. In most patients nitrogen requirements can be more simply computed from urinary nitrogen losses. Our experience has shown, however, that these fluctuate greatly even over short periods of feeding, particularly in acutely ill and septic patients. For these reasons, therefore, the design of the present, as well as our most recent trials, ${ }^{56}$ has been based on randomising patients, whose nutrient requirements are not individually assessed before entry, to treatment groups receiving fixed volumes of diet whose composition is not altered during the study protocol. Consequently, if it is planned to administer 21 polymeric diet $/ 24 \mathrm{~h}$ by continuous infusion through the nasogastric route to patients with normal gastrointestinal function, the clinical significance of our data would be that significantly better nitrogen retention will result from the use of a nitrogen dense diet containing 9.0 $\mathrm{gN} / \mathrm{l}$ as compared with diets containing 6 to $7.5 \mathrm{gN} / 1$.

For the last 10 years or so it has been traditional to prescribe enteral diets with an energy density of $1 \mathrm{kcal} / \mathrm{ml}$ and a nitrogen content of approximately 5 to $6 \mathrm{~g} / 1 .{ }^{8}$ Controlled trials show that almost half the patients so treated will not attain positive nitrogen balance. ${ }^{4-6}$ In the acutely ill patient this will be so, at least initially, as a consequence of the neuroendocrinological response to injury. ${ }^{22}$ In others, however, an inadequate intake of nitrogen has been shown to be important. ${ }^{56}$ Inadequate intakes occur for technical reasons such as the use of small volume diet containers, ${ }^{5}$ the poor performance of fine bore nasogastric feeding tubes, ${ }^{7}$ and the use of starter regimes, whereby full strength diets are introduced gradually over a two to four day period to reduce the incidence of gastrointestinal side effects. ${ }^{6}$ It has been the fear that more concentrated and relatively hypertonic diets would give rise to unacceptably high incidences of gastrointestinal side effects that has probably discouraged physicians from administering these routinely as a measure of increasing nutrient intake. In the present study all three diets were equally well tolerated and the incidence of gastrointestinal side effects in the three treatment groups was very low, and side effects did not occur any more commonly during use of the energy dense $(1.5 \mathrm{kcal} / \mathrm{ml})$ nitrogen dense $(9.4 \mathrm{gN} / 1)$ diet than during the use of the standard $(1 \mathrm{kcal} / \mathrm{ml}, 6.3 \mathrm{gN} / \mathrm{l})$ polymeric diet, this despite the fact that starter regimes were not used. Our findings provide no support, therefore, for suggestions that nutrient dense diets containing up to
$1.5 \mathrm{kcal} / \mathrm{ml}$ and $9.4 \mathrm{gN} / \mathrm{ml}$ with an osmolality of 550 $\mathrm{mmol} / \mathrm{kg}$ will be tolerated any less than the more widely used standard polymeric diets, as long as gastrointestinal function is normal and the diets are infused continuously over 24 hours.

One surprising finding of the present study was that higher nitrogen losses were found in all three treatment groups as compared with those documented previously in our unit. ${ }^{46}$ This might be partly because of the relatively high proportion of the patient population included in the present study with neurological disease and multiple trauma. High nitrogen losses are now recognised with neurological disease $^{2324}$ as well as with fractures and soft tissue injury. The remaining patients still had higher nitrogen losses, however, than similar patient groups previously reported. ${ }^{46}$ In the present study we have routinely measured total urinary nitrogen losses directly using an automated chemiluminescence technique ${ }^{13}$ rather than computing losses indirectly from urinary urea excretion data. ${ }^{25}$ We have recently shown that the urinary urea method of assessing nitrogen losses may provide an underestimate in significant numbers of patients. ${ }^{13}$ The possibility exists, therefore, that some of the previously published nitrogen balance data computed from urinary urea losses may have been spuriously high. If this is indeed the case, and nitrogen losses in our enterally fed patients are higher than previously thought, there would seem to be even more reason for routinely prescribing nitrogen dense diets.

Finally, it should be reemphasised that two of the diets used in the present study had an energy density of $1.5 \mathrm{kcal} / \mathrm{ml}$ as compared with the $1.0 \mathrm{kcal} / \mathrm{ml}$ density of the standard polymeric diet. The two energy dense diets were formulated before it was realised that the energy requirements of acutely ill patients requiring nutritional support had been overestimated. ${ }^{26}$ It should not necessarily be assumed, therefore, from the present study that the benefits gained from administering a polymeric diet with a nitrogen content of $9.4 \mathrm{~g} / 1$ are dependent upon an energy density as high as $1.5 \mathrm{kcal} / \mathrm{ml}$. Controlled studies are currently in progress in our unit investigating the possibility that similar nitrogen balance data can be obtained using nitrogen dense diets that have a lower $(1 \mathrm{kcal} / \mathrm{ml})$ energy density. It seems particularly pertinent to investigate this issue of diet formulation as recent data show that intraduodenal infusion of high calorie loads actually exerts an inhibitory effect on pancreatic exocrine function. ${ }^{27}$ It should be reiterated, however, that in our experience complete volumes of prescribed enteral diet are often very difficult to administer and, therefore, the use of nutrient dense enteral diets may not, in practice, mean the increase in nutrient intake anticipated. 
In conclusion, our findings support the routine use of nitrogen dense polymeric diets which appear to be well tolerated as long as they are administered by continuous 24 hour infusion to patients with normal gastrointestinal function. The current widespread use of polymeric diets with a nitrogen density in the range 5 to $6 \mathrm{~g} / \mathrm{l}$ is to be discouraged as a significant proportion of patients are likely to remain in negative nitrogen balance despite enteral feeding.

The authors are grateful to Nutricia, Zoetermeer, Holland for financial support, and wish to thank the nursing and dietetic staff of the Central Middlesex Hospital, without whose help this research would not have been possible.

\section{References}

1 Jones BMJ, Payne S, Silk DBA. Indications for pumpassisted enteral feeding. Lancet 1980; i: 1057-8.

2 Silk DBA. Enteral nutrition. Med Int 1982; 1: 668-73.

3 Jones DC, Rich AJ, Wright PD, Johnston IDA. Comparison of proprietary elemental and whole-protein diets in unconscious patients with head injury. $\mathrm{Br} \mathrm{Med} \mathrm{J}$ 1980; 280: 1493-5.

4 Jones BMJ, Lees R, Andrews J, Frost P, Silk DBA. Comparison of an elemental and polymeric enteral diet in patients with normal gastrointestinal function. Gut 1983; 24: 78-84.

5 Keohane P, Attrill H, Love M, Frost P, Silk DBA. A controlled trial of aseptic enteral diet preparation significant effects on bacterial contamination and nitrogen balance. Clin Nutr 1983; 2: 119-22.

6 Keohane PP, Attrill H, Love M, Frost P, Silk DBA. Relation between osmolality of diet and gastrointestinal side effects in enteral nutrition. Br Med J 1984; 288: 67880.

7 Keohane PP, Attrill H, Jones BMJ, Silk DBA. Limitations and drawbacks of 'fine Bore' nasogastric feeding tubes. Clin Nutr 1983; 2: 85-6.

8 Silk DBA. Diet formulation and choice of enteral diet. Gut 1986; 27 (suppl 1): 40-6.

9 Rees RGP, Attrill H, Quinn D, Silk DBA. Improved design of nasogastric feeding tubes. Clin Nutr 1986; 5: 203-7.

10 Jelliffe DB. Assessment of the nutritional status of the community. Geneva: World Health Organisation, 1966.

11 Ingenbleek Y, Van den Shrieck HG, De Nayer P, De Visscher M. Albumin, transferrin and the thyroxinebinding prealbumin/retinol-binding protein (TBPARBP) complex in assessment of malnutrition. Clin Chim Acta 1975; 63: 61-7.

12 Beetham R, Dawnay A, Landon J, Cattell WR. A radioimmunoassay for retinol-binding protein in serum and urine. Clin Chem 1985; 31: 1364-7.

13 Grimble GK, West MFE, Acuti ABC, et al. Assessment of an automated chemiluminescence nitrogen analyser for routine use in clinical nutrition. J Parent Enteral 1988; 12: 100-6.

14 Keohane PP, Attrill H, Jones BJM, Brown I, Frost P, Silk DBA. The roles of lactose and Clostridium difficile in the pathogenesis of enteral feeding associated diarrhoea. Clin Nutr 1983; 1: 259-64.

15 Blackburn GL, Bistrian BR, Main BS, Schlamm HT, Smith MF. Nutritional and metabolic assessment of the hospitalised patient. J Parent Enteral Nutr 1977; 1: 1122.

16 Molnar JA, Bell SJ, Goodenough RD, Burk JF. Enteral nutrition in patients with burns or trauma. In: Rombeau $\mathrm{JL}$, Caldwell MD, eds. Enteral and tube feeding. Philadelphia: WB Saunders Co, 1984: 412-33.

17 Cheng AHR, Gomez A, Bergan JG, Lee T-C, Monckeberg F, Chichester CO. Comparative nitrogen balance study between young and aged adults using three levels of protein intake from a combination wheatsoy-milk mixture. Am J Clin Nutr 1978; 31: 12-22.

18 World Health Organisation Technical Report Series no. 724. Energy and protein requirements. Report of a joint FAO/WHO/UNU expert consultation. Geneva: WHO, 1985.

19 Silk DBA. Towards the optimization of enteral nutrition. Clin Nutr 1986; 6: 61-74.

20 Jéquier E. Direct and indirect calorimetry in man. In: Garrow JS, Halliday D, eds. Substrate and energy metabolism in man. London: John Libbey, 1985: 82-92.

21 Head CA, McManus CB, Seitz S, Grossman GD, Staton GW, Heymsfield SB. A simple and accurate indirect calorimetry system for assessment of resting energy expenditure. J Parent Enteral Nutr 1984; 8: 45-8.

22 Cuthbertson DP. The metabolic response to injury and its nutritional implications: retrospect and prospect. J Parent Enteral Nutr 1979; 3: 108-29.

23 Clifton GL, Robertson CS, Grossman RG, Hodge S, Folitz R, Garza C. The metabolic response to severe head injury. J Neurosurg 1984; 60: 687-96.

24 Twyman D, Young AB, Ott L, Norton JA, Bivins BA. High protein enteral feedings: a means of achieving positive nitrogen balance in head injured patients. J Parent Enteral Nutr 1985; 9: 679-84.

25 Lee HA, Hartley TF. A method of determining darly nitrogen requirements. Postgrad Med J 1973; 51: 441-5.

26 Jeejeebhoy KN. Energy metabolism in the critically ill. In: Garrow JS, Halliday D, eds. Substrate and energy metabolism in man. London: John Libby, 1985: 93-101.

27 Pfeiffer A, Vidon N, Chayvialle JA, Franchisseur C, Bovet M, Bernier JJ. Effect of perfusing jejunum with various caloric loads on hormonal and pancreatic responses in normal man. Clin Nutr [suppl] 1986; 5: 0.71 . 